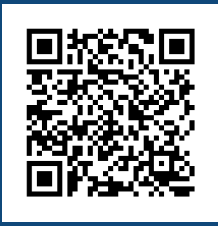

Keywords:

Colombian mahogany

Germination

Gibberellins

Lecythidaceae

Historic:

Received 26/09/2018

Accepted 22/05/2019

Correspondence: aprato@agrosavia.co
Andrés Iván Prato Sarmiento ${ }^{1+, a}$, Diego Alejandro Zaraté Caicedo ${ }^{1 b, 2}$, Jhon Jairo Zuluaga Peláez ${ }^{1 \mathrm{c}, 3}$, Sandra Liliana Castañeda Garzón ${ }^{\mathrm{ld}, 4}$

\section{SEEDLING EMERGENCY AND BIOMETRY OF FRUITS AND SEEDS OF Cariniana pyriformis FROM THE MIDDLE MAGDALENA VALLEY, COLOMBIA}

PRATO, A. I.; ZARATÉ, D. A.; ZULUAGA, P. J. J.; GARZON, S. L. C. Seedling emergency and biometry of fruits and seeds of Cariniana pyriformis from the middle Mgdalena Valley, Colombia. CERNE, v. 25, n. 2, p.221-229, 2019.

\section{HIGHLIGHTS}

Cariniana pyriformis shows a higher variability in fresh mass per fruit (35\%).

One kilogram corresponds to 6715 seeds with II\% humidity.

The application of $\mathrm{GA}_{3}$ allows accelerating and synchronizing seedling emergence.

Immersion for 24 hours in $1000 \mathrm{mg} \cdot \mathrm{L}^{-1}$ of $\mathrm{GA}_{3}$ is recommended

\section{ABSTRACT}

Aiming at contributing to the knowledge of the biology and propagation of Cariniana pyriformis Miers, a native species with high timber and ecological attributes, ripe fruits were harvested. Initially, in 400 seeds and 320 fruits, the size, fresh mass, seed water content, number of seeds per fruit, number of seeds per kilogram and fruit color were assessed. Then, a homogenous seed sample was immersed for 24 hours in five doses $(0$, $250,500,750$ and $\left.1000 \mathrm{mg}^{-L^{-1}}\right)$ of gibberellins $\left(\mathrm{GA}_{3}\right)$ and cultivated in a greenhouse. For this, a completely randomized design was adopted with six replications of 25 seeds each. Fruits and seeds showed values, on average \pm standard deviation, of $76.1 \pm 1 \mathrm{I} \mathrm{mm}$ and $48.1 \pm 8.2 \mathrm{~mm}$ in length, and $49.6 \pm 5 \mathrm{~mm}$ and $7.2 \pm 0.7 \mathrm{~mm}$ of width, respectively, with $62.3 \pm 22.3 \mathrm{~g}$ of fresh mass per fruit and $13 \pm 3.1$ seeds per fruit. One kilogram corresponded on average to 6715 seeds with $11 \%$ water content. In the greenhouse, emergence speed index and emergency percentage of seedlings increased as the $\mathrm{GA}_{3}$ dose increased, allowing a more concentrated emergency process in a shorter period. Highest variation was found for fresh mass per fruit $(\mathrm{CV}=35 \%)$ and number of seeds per fruit $(\mathrm{CV}=24 \%)$. Immersion in $1000 \mathrm{mg} \cdot \mathrm{L}^{-1}$ in $\mathrm{GA}_{3}$ for 24 hours triggers seedling emergency in C. pyriformis (approx. $71 \%$ ), and then it is recommended for plant propagation, since the treatment accelerated and synchronized seedling emergency. 


\section{INTRODUCTION}

Abarco, chibugá, piloncillo, bacú or Colombian mahogany (Cariniana pyriformis Miers) is a forest species belonging to the Lecythidaceae family and Lecythidoideae subfamily (Huang et al., 2015; Cárdenas et al., 2015). This subfamily is restricted to tropical regions of the Western Hemisphere and includes II genera and 210 described species, with the Amazon basin and non-flooded lowland forests of the Guianas as the center of diversity (Huang et al., 2015). Particularly, the genus Cariniana includes 17 species, eight of which occur naturally in Brazil (Smith et al., 2015).

C. pyriformis is a native tree species that occurs in Northwestern Colombia, Eastern Panama and Maracaibo Lake Basin in Venezuela (Mori et al., 2017). The high wood strength and durability make this a promising species for forestry and agroforestry systems (AFS) associated to cacao, depending on the climatic conditions of a particular region (Agudelo - Castañeda et al., 2018; Suarez et al., 2018). The species is categorized as Critically Endangered, being the reason why some municipalities in Colombia maintain a ban on a ban on commercial logging (Cárdenas et al., 2015). In addition to its high timber attributes, abarco has the potential to be recommended in ecological restoration programs, just as the species Cariniana legalis (Mart.) Kuntze and Cariniana estrellensis (Raddi) Kuntze that have been used in coffee AFS in Brazil (Karsten et al. al., 2014; Nicodemo et al., 2016).

Apart from some studies carried out in certain geographical areas of Colombia, e.g. Antioquia, Choco and Córdoba (Betancur and Raigosa, 1973; Diez and Moreno, 1998; Gómez, 2010; Espitia et al., 2017), information about fruit and seed morphology is scarce for this species. These aspects are crucial since they are related to dispersal strategies, establishment of seedlings in the field and detection of genetic variability in populations or individuals. In addition, it also contributes to studies on ecological succession and regeneration of forest ecosystems (Silva et al., 2013; Zhu et al., 2016; Cangussu et al., 2018).

Abarco seeds could be classified as intermediate orthodox, allowing their storage for extended periods according to Betancur and Raigosa (1973). However, the demand for seeds is difficult due to its suprannual fructification or even scarce in some years (Betancur and Raigosa, 1973; Gómez, 2010). Additionally, because of the constant decrease in number of adult individuals, the development of protocols that facilitate the propagation and massive production of seedlings is required.
According to the aforementioned, the aim of this study was to characterize the biometry and some physical properties of fruits and seeds of $C$. pyriformis from native trees of the Middle Magdalena Valley in Santander department (Colombia), as well as the effect of gibberellins application on seedling emergency.

\section{MATERIAL AND METHODS}

\section{Study area and tree selection}

During April and August 2016 in the rural area of the municipality of El Carmen de Chucuri, department of Santander (Colombia), mature fruits of four wild adult trees of $C$. pyriformis, known hereinafter as TI, T2, T3 and $\mathrm{T} 4$, were harvested when these initiated natural operculum opening (Table I). The selection was made according to evidence of previous fruiting, good sanitary status and a minimum distance of $100 \mathrm{~m}$ between each tree to avoid related crosses. The limited access to private properties where some trees were located and reduction of the populations sampled in the region conditioned the number of adult individuals selected for this study.

Harvest was carried out with a sickle in the upper third of the crown. According to the Köppen classification system (Köppen, 1918), the region has an equatorial tropical climate (Af) with rainfall distributed in two periods, from April to May and from October to November, i.e. a bimodal regime. The average temperature and precipitation (of 20 years) is $24^{\circ} \mathrm{C}$ and $2580 \mathrm{~mm}$, respectively, according to the climatological station of Instituto de Hidrología, Meteorología y Estudios Ambiental (IDEAM), and to $10 \mathrm{~km}$ of distance from the study area.

Climatic information during fruit the formation period (October 2015 to August 2016) as well as the geographical location of trees were carried out during field visits, made every three weeks. Figure IA and Figure IB show the data recorded during fruit formation period (October 2015 to August 2016) and the geographical location of trees (for more detail on the phenological monitoring, please consult Pelaez et al., 2018).

One day after harvesting, fruits were transported to the facilities of the Research Center C.I. La Suiza of Corporación Colombiana de Investigación Agropecuaria (AGROSAVIA), located in the municipality of Rionegro, Santander $\left(7^{\circ} 22^{\prime} \mathrm{II} . \mathrm{I} \mathrm{N} ; 73^{\circ} 10^{\prime} 39.2^{\prime \prime} \mathrm{W} ; 530 \mathrm{~m}\right.$ of altitude). Fruits were identified by tree and exposed to to the sun in sunny days and collected at sunset to facilitate seed extraction during two weeks (at a temperature 
TABLE I Harvest date, altitude, plant height, diameter at breast height $(\mathrm{DBH})$ and geographical coordinates of the Cariniana pyriformis trees selected.

\begin{tabular}{cccccc}
\hline Tree & Harvest date & Altitude $(\mathrm{m})$ & Plant height $(\mathrm{m})^{*}$ & $\mathrm{DBH}(\mathrm{cm})$ & Geographical coordinates \\
\hline T1 & $25 / 04 / 2016$ & 350 & 30.3 & 45.3 & $6^{\circ} 40^{\prime} 50.79^{\prime \prime} \mathrm{N} ; 73^{\circ} 36^{\prime} 27.3 I^{\prime \prime} \mathrm{W}$ \\
T2 & $25 / 04 / 2016$ & 362 & 28.9 & 55.5 & $6^{\circ} 42^{\prime} 2.6^{\prime \prime} \mathrm{N} ; 73^{\circ} 34^{\prime} 21.0 I^{\prime \prime} \mathrm{W}$ \\
T3 & $09 / 08 / 2016$ & 245 & 29.5 & 79.3 & $6^{\circ} 46^{\prime} 32.25^{\prime \prime} \mathrm{N} ; 73^{\circ} 35^{\prime} 19.08^{\prime \prime} \mathrm{W}$ \\
T4 & $09 / 08 / 2016$ & 480 & 33.2 & 86.2 & $6^{\circ} 4 I^{\prime} 14.84^{\prime \prime} \mathrm{N} ; 73^{\circ} 36^{\prime} 44.16^{\prime \prime} \mathrm{W}$ \\
\hline
\end{tabular}

* Height estimated using an inclinometer (Suunto Pm-5/360 P)
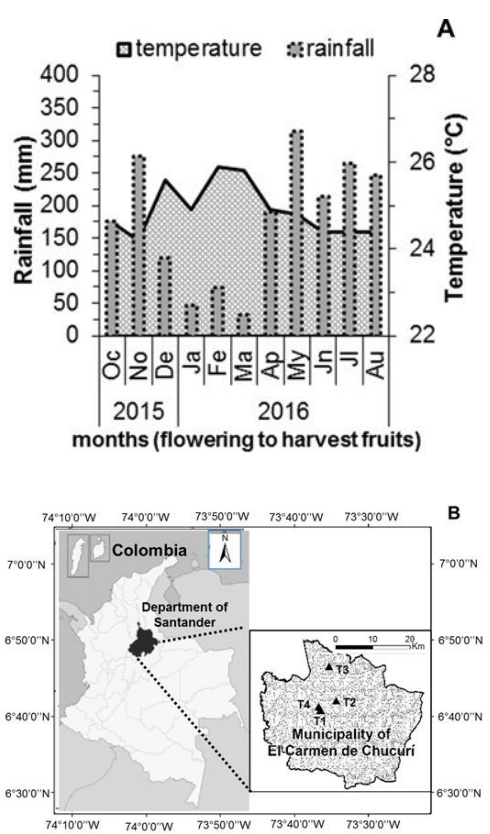

FIGURE I A) Precipitation (bars) and monthly temperature (polygon) during the fruit formation period, and B) geographical location of Cariniana pyriformis trees assessed.

of $24.5{ }^{\circ} \mathrm{C}$ and $90.4 \%$ relative humidity). These were placed inside well-ventilated environments to avoid rainfall. As seeds were released these were stored in a refrigerator inside plastic containers (at a temperature of $3{ }^{\circ} \mathrm{C}$ and $30 \%$ relative humidity). Subsequently, the following experiments were established.

\section{Experiment I: biometrics of fruits and seeds}

The maturation state of the fruits was established by reflectance analysis in the red, green and blue spectra with a color analyzer (Lutron RGB-100), and images obtained were reproduced in a specific color reproduction software (Photoshop CS6). The resulting fruit value was the average of three points in the apical, intermediate and basal regions.

For each tree, 80 fruits without visual symptoms of diseases, plagues, physical damage (e.g. perforations), or that were broken were randomly selected per tree. The number of seeds per fruit, fruit fresh mass, fruit length and width in the operculum region were assessed. A precision scale $(0.0 \mathrm{l} \mathrm{g})$ was used for weight recordings and a digital caliper (precision of $0.01 \mathrm{~mm}$ ) was used for length measurements. The seeds considered in this trial had a mature stage, were intact, and without visual symptoms of pest attack.

The seeds water content was established by the oven method at $105{ }^{\circ} \mathrm{C}$ for 24 hours, using three replications of $2 \mathrm{~g}$, weighed in a precision scale $(0.01 \mathrm{~g})$, and the results expressed as percentage (Brasil, 2009). The weight of 1000 seeds was established by the average value obtained with eight replications of 100 seeds using an electronic scale $(0.01 \mathrm{~g})$, being then calculated the number of seeds per kilogram (Brasil, 2009).

For each tree, 100 seeds were randomly selected, and their length (including its winged section), width, and thickness were measured with a digital caliper ( 0.01 $\mathrm{mm}$ ). Moreover, wing width per seed was measured in its middle section.

A completely randomized experimental design with four treatments (trees: TI, T2, T3 and T4) and six replicates of 25 seeds per tree were employed. For fruits, four replications of 20 fruits per tree were used, and for fruit coloring, five replications of eight fruits per tree were employed. The biometric data of fruits and seeds were analyzed for their adherence to normality through the Shapiro-Wilk test, and its frequencies distributed in six class intervals, calculating means, minimums, maximums, standard deviations and the coefficient of experimental variation.

Experiment 2: Gibberellins and seedling emergency

From a homogenized seed sample of $300 \mathrm{~g}$ storage for 35 days in the refrigerator, the required seeds for experiment was disinfected with sodium hypochlorite (10\% for 10 minutes) and washed three times with distilled water. Since fruiting of the individuals selected was not synchronous, the harvest obtained in August 2016 was selected. Subsequently, seeds (without wing) were immersed for 24 hours in five doses of $\mathrm{GA}_{3}$ $\left(0,250,500,750\right.$ and $\left.1000 \mathrm{mg} \cdot \mathrm{L}^{-1}\right)$ in plastic containers containing $100 \mathrm{~mL}$ of solution. The control treatment comprised immersion for 24 hours in distilled water. Seeds were planted in plastic boxes $(12 \mathrm{~cm} \times 12 \mathrm{~cm} \times 3$ $\mathrm{cm}$, length $\mathrm{x}$ width $\mathrm{x}$ height) using washed and sterilized river sand (oven at $120^{\circ} \mathrm{C}$ for 2 hours). Propagation was 
carried out in a greenhouse with an anti-thermal plastic cover that provides $50 \%$ shade. Irrigation was applied evenly to maintain adequate moisture in the trays (to approximately $60 \%$ of field capacity).

The number of normal emerged seedlings, when the cotyledons exceeded the substrate line, was recorded every two days until the stabilization of all the treatments, lasting 54 days after sowing (DAS). Seedling emergency (SE), mean emergence time (MET), emergence speed index (ESI) and relative emergence frequency (REF) were calculated according to the formulas described by Ranal and Santana (2006). In the experimental period, the minimum, maximum and mean temperature $\left(19.5^{\circ} \mathrm{C}, 41.6^{\circ} \mathrm{C}\right.$ and $\left.26.6^{\circ} \mathrm{C}\right)$ and relative humidity $(4 \mathrm{I} .5 \%, 100 \%$ and $87.8 \%)$ were recorded every 10 min using a data logger (CEM DT- I $7 I^{\circledR}$ ).

A completely randomized experimental design with six replications of 25 seeds was employed, referring to five doses of $\mathrm{GA}_{3}\left(0,250,500,750\right.$ and $\left.1000 \mathrm{mg} \cdot \mathrm{L}^{-1}\right)$.

\section{Statistical analysis}

Data on biometric variables were subjected to an analysis of variance followed by the Tukey test $(p<0.05)$ for the parametric results. When the normality and homogeneity of the variances were not verified by the Shapiro-Wilk and Levene tests, respectively, the nonparametric analysis (Kruskal-Wallis) was used, and followed by the Dunn test $(p<0.05)$. The SE, MET and ESI variables were subjected to polynomial regression analysis up to a third grade. When the F-test indicated a $5 \%$ probability of significance for more than one regression, the equation of higher significance and the coefficient of determination was selected. All the analyzes were carried out using the statistical program $R$ version 3.3.2 (R Core Team, 2017).

\section{RESULTS}

\section{Experiment I: biometrics of fruits and seeds}

There were significant differences for all the morphometric variables of fruits and seeds among the trees. Only wing $(p<0.5 \mathrm{I})$ and seed width $(\mathrm{p}<0 . \mathrm{II})$ showed a normal distribution (Table 2, Table 3, and Figure 2).

Fruit morphometry showed wide variability for fresh mass $(\mathrm{CV}=35.7 \%)$, with a predominance between 40 and $60 \mathrm{~g} \mathrm{(40 \% )} \mathrm{and} \mathrm{from} 60$ to $80 \mathrm{~g}(22.5 \%)$, with an average of $62.3 \mathrm{~g}$ (Figure 2A). The lowest value was recorded in the T3 tree (mean $=38.8 \mathrm{~g})$ and the highest in T2 (mean $=94.3 \mathrm{~g}$ ). However, there was a slight variation for fruit length with the majority inserted in classes 7 and $8 \mathrm{~cm}(35.4 \%)$, and in 8 to $9 \mathrm{~cm}(23.2 \%)$, with an average of $7.6 \mathrm{~cm}$ (Figure 2B). Fruit width had a predominance between 4.3 to $5.3 \mathrm{~cm}(6 \mathrm{I} .6 \%)$ and an average of $5 \mathrm{~cm}$ (Figure 2C). These two dimensions showed a coefficient of experimental variation of less than $15 \%$.

Mature fruits of abarco were characterized by their dark brown coloration (Table 2). The number of seeds per fruit had a high coefficient of variation (24.2\%), predominating between II to I 4 seeds (38.5\%) and with an average of 13 seeds (Figure 2D). The T2 tree had the highest number of seeds per fruit (I5).

Seed dimensions also showed similar values (Table 3 and Figures 2E, F, G and H). Mean length was $48.1 \mathrm{~mm}$ and there was a predominance between 37 and $51 \mathrm{~mm}$

TABLE 2 Means of fresh mass (MF), length (LF), width (WF) and RGB colors of fruits in four adult $C$. pyriformis trees.

\begin{tabular}{|c|c|c|c|c|c|c|c|}
\hline \multirow{2}{*}{ Tree } & \multirow{2}{*}{$\begin{array}{l}\text { MF } \\
(\mathrm{g})^{\mathrm{B}} \\
\end{array}$} & \multirow{2}{*}{$\frac{\mathrm{LF}^{\mathrm{A}}}{(\mathrm{c}}$} & \multirow{2}{*}{$\begin{array}{l}\text { WF } \\
\end{array}$} & \multicolumn{3}{|c|}{ Reflectance values $*$} & \multirow{2}{*}{ Color } \\
\hline & & & & $\mathrm{R}^{\mathrm{B}}$ & $\mathrm{G}^{\mathrm{B}}$ & $\mathrm{B}^{\mathrm{B}}$ & \\
\hline TI & 55.7 bc & $7.3 c$ & $4.6 \mathrm{~b}$ & $25.9 \mathrm{bc}$ & $20.8 \mathrm{bc}$ & 17.5 bc & \\
\hline T2 & $94.3 \mathrm{a}$ & $8.9 \mathrm{a}$ & $5.5 \mathrm{a}$ & $25.7 c$ & $20.4 c$ & I7.I c & \\
\hline T3 & $38.8 \mathrm{c}$ & $6.2 \mathrm{~d}$ & $4.5 \mathrm{~b}$ & $37.3 \mathrm{ab}$ & $30.4 \mathrm{ab}$ & $25.8 \mathrm{ab}$ & \\
\hline T4 & $60.5 \mathrm{ab}$ & $8.0 \mathrm{~b}$ & $5.2 \mathrm{ab}$ & $46.6 \mathrm{a}$ & $35.7 \mathrm{a}$ & $28.5 \mathrm{a}$ & \\
\hline Mean & 62.33 & 7.61 & 4.96 & 33.9 & 26.8 & 22.2 & \\
\hline
\end{tabular}

RGB: * Reflectance values in the red, green and blue spectra employing a color analyzer (Lutron PCE-I002). Means with the same letter in the column do not differ significantly $(p<0.05)$ from each other according to Tukey $(A)$ and Kruskall-Wallis (B) tests.

(59.4\%); average width presented a value of $7.2 \mathrm{~mm}$ with a predominance ranged between 7 to $8 \mathrm{~mm}$ (5I.1\%); and average thickness showed a value of $4.4 \mathrm{~mm}$ and was predominantly between 4 and $4.8 \mathrm{~mm}$ (45.3\%). Furthermore, dimensions were higher in the T4 tree and smaller in the TI compared to the others. As for wing width values, the average was $13.1 \mathrm{~mm}$ and predominance ranged between II and $14 \mathrm{~mm}$ (38.5\%). The coefficient of experimental variation for seed dimensions was between 10 and $17 \%$. An average of 6715 seeds per $\mathrm{kg}$ was found, and seeds had $10.9 \%$ water content, which corresponds to a harvest of 523 fruits.

\section{Experiment 2: Gibberellins and seedling emergency}

All the physiological variables evaluated had a significant effect due to the application of $\mathrm{GA}_{3}$ (Figure 3). Seedling emergency showed a positive linear dependence $\left(R^{2}=0.81, p<0.05\right.$, Figure $\left.3 A\right)$ in relation to increasing doses of $\mathrm{GA}_{3}$, obtaining a maximum of $73.5 \%$ when using 750 and $1000 \mathrm{mg} \cdot \mathrm{L}^{-1}$ (Figure 3A). However, seed germination in absence of a phytoregulator had a value of $51.1 \%$. In addition, increasing doses of $\mathrm{GA}_{3}$ 

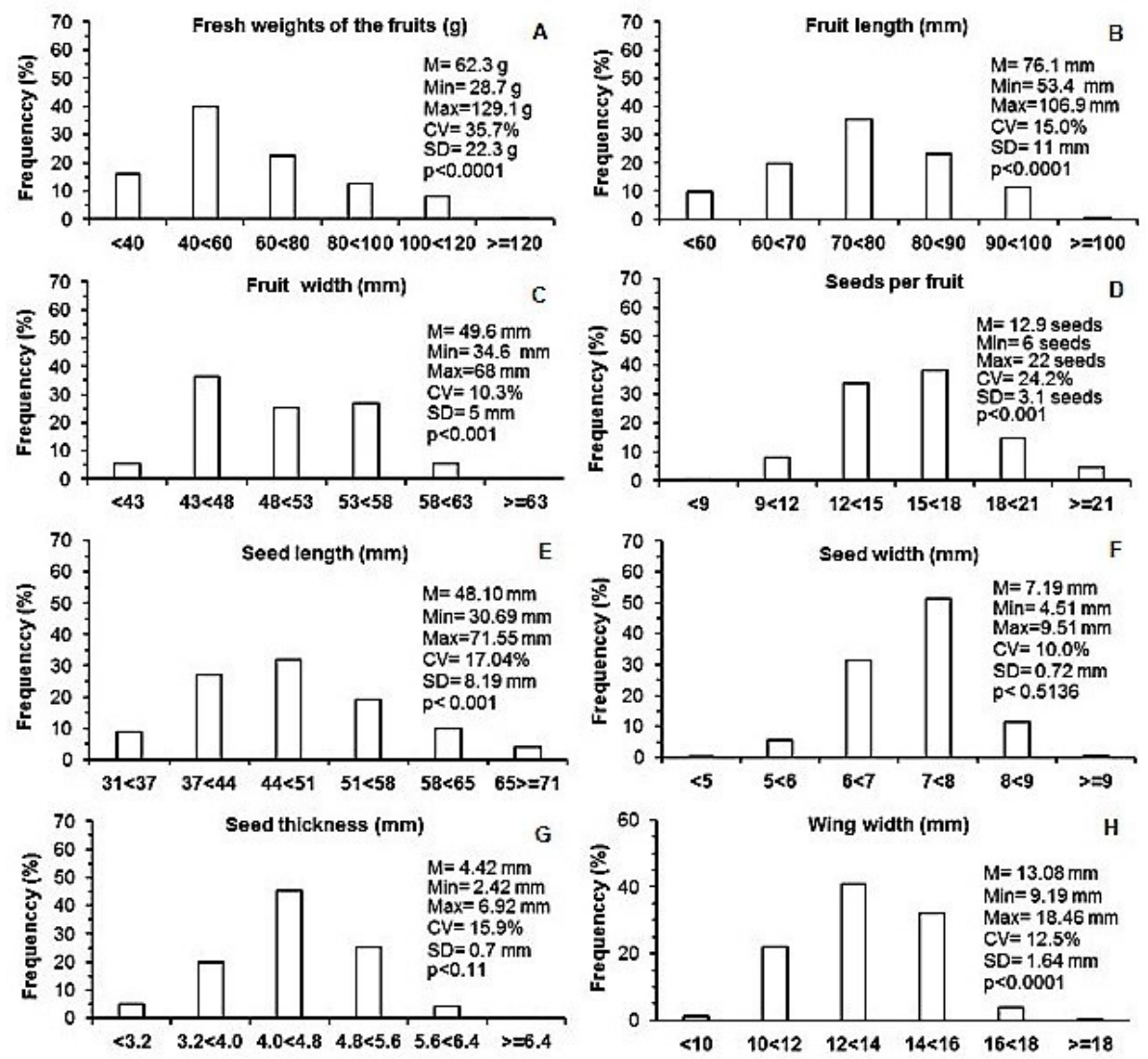

FIGURE 2 Frequency distributions in six intervals, mean (M), minimum value (Min), maximum value (Max), coefficient of variation (CV), standard deviation (SD) and level of significance of the Shapiro-Wilk normality test $(\mathrm{p})$ for fresh mass per fruit $(A)$, fruit length $(B)$, fruit width $(C)$, seeds per fruit $(D)$, seed length $(E)$, seed width $(F)$, seed thickness $(G)$ and wing width $(H)$ of $C$. pyriformis. $\mathrm{n}=320$ fruits and 400 seeds.

TABLE 3 Means of seeds number per fruit (NSF), seeds number per $\mathrm{kg}$ (NSK), seed length (LS), width (WS) and thickness (TS), wing width (WWS) and seed water content (SWC) for four C. pyriformis trees.

\begin{tabular}{|c|c|c|c|c|c|c|c|}
\hline Tree & $\mathrm{NSF}^{\mathrm{B}}$ & NSK * & LSA & WSA & TS A & WWS & SWC \\
\hline & \multicolumn{2}{|c|}{ (number of seeds) } & & \multicolumn{2}{|c|}{$(\mathrm{mm})$} & & $(\%) *$ \\
\hline $\mathrm{TI}$ & $11.9 \mathrm{~b}$ & 6224.5 & & $6.7 \mathrm{I} \mathrm{b}$ & $3.83 c$ & $13.75 \mathrm{a}$ & 13.4 \\
\hline T2 & & & & & & & \\
\hline T3 & & & 44.9 & $7.13 \mathrm{ab}$ & $4.43 \mathrm{~b}$ & $40 \mathrm{~b}$ & 9.4 \\
\hline T4 & 13.3 & & $57.14 \mathrm{a}$ & $7.48 \mathrm{a}$ & $5.04 \mathrm{a}$ & $13.80 \mathrm{a}$ & 9.1 \\
\hline Mean & 13.0 & 6715 & 47.74 & 7.19 & 4.41 & 13.1 & 10.9 \\
\hline
\end{tabular}

Means with the same letter in the column do not differ significantly $(p<0.05)$

from each other according to Tukey $\left({ }^{(}\right)$and Kruskal-Wallis $\left({ }^{B}\right)$ tests. ${ }^{*}$ No statistical analysis was carried out

decreased the MET, observing a lineal behavior $\left(R^{2}=\right.$ $0.97, p<0.0$ I, Figure $3 \mathrm{~B})$, which means a reduction of up to 10 days when the $1000 \mathrm{mg} \cdot \mathrm{L}^{-1}$ dose (27 days) was used, compared to the control treatment. This positive influence of $\mathrm{GA}_{3}$ was confirmed by the ESI that showed a linear response $\left(R^{2}=0.81, p<0.05\right.$, Figure $\left.3 C\right)$, reaching a maximum of 6.01 with the dose of $1000 \mathrm{mg} \cdot \mathrm{L}^{-1}$. In contrast, the other treatments had lower values than the $1000 \mathrm{mg} \cdot \mathrm{L}^{-1}$ treatment.
In general, seedling emergency comprised a period from 16 to 50 DAS, with marked differences in REF according to the dose (Figure 3D). With the exception of treatments 750 and $1000 \mathrm{mg} \cdot \mathrm{L}^{-1}$ that showed a polygon with unimodal character and a more homogeneous emergency process, the other treatments were characterized by being polymodal and with several peaks, between two to four.

The mean of this trial had a MET of 32.5 days. Consequently, the MET values for 0 (37.6 days) and 250 (35.I days) $\mathrm{mg}^{-\mathrm{L}^{-1}}$ of $\mathrm{GA}_{3}$ moved to the right of the polygon, observing a large proportion of seedlings (21\%) emerging between 36 and 40 DAS (Figure 3D). Furthermore, there was also a peak of lower intensity between 44 and 48 DAS, where up to $10 \%$ of the seedlings emerged. On the contrary, the doses of 750 (30 days) and 1000 (27.4 days) mg. L-1 I of $\mathrm{GA}_{3}$ showed a peak between 22 and 26 DAS of $38 \%$ of seedlings emerged, i.e., to the left of the polygon. Finally, in these two doses, the emergency decreases until the end of the process. 

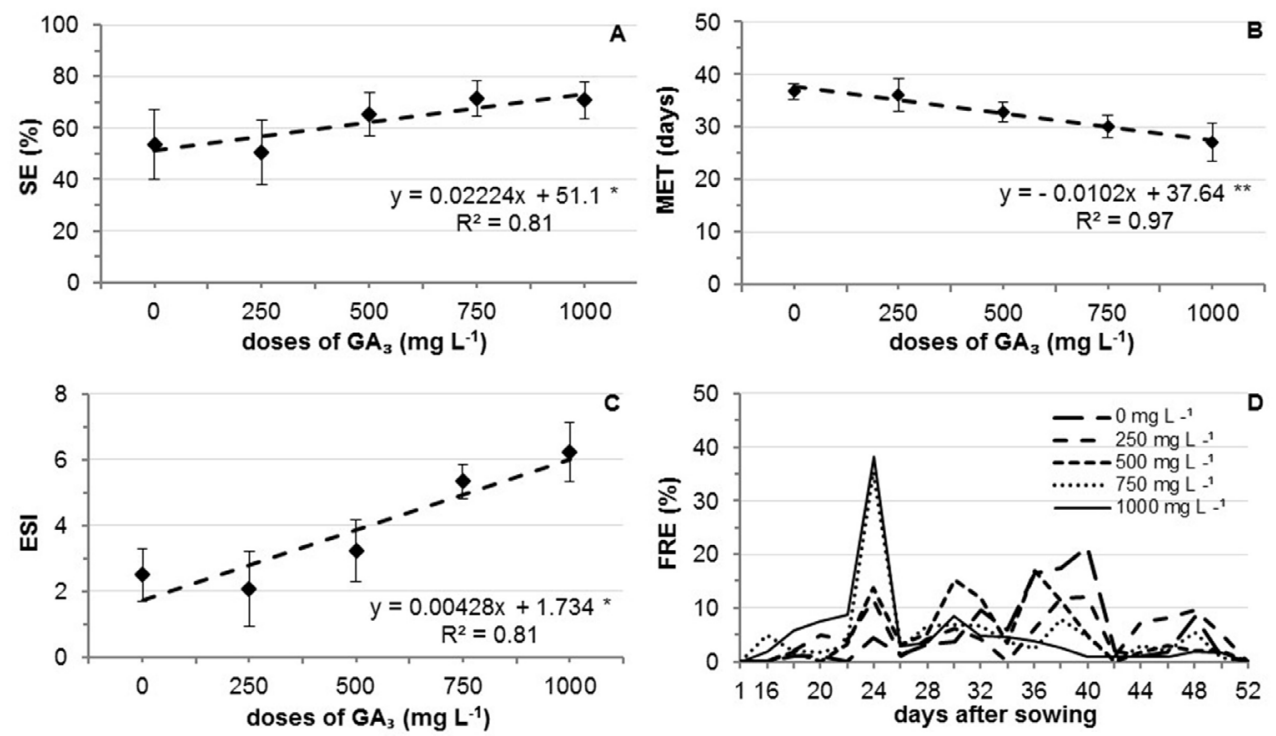

FIGURE 3 Means for A) seedling emergency (SE), B) mean emergence time (MET), C) emergence speed index (ESI), and D) relative emergence frequency (REF) for Cariniana pyriformis. *, *** significant at $5 \%$ or $1 \%$ for the F-test, respectively. Vertical bar indicates vertical bar indicates desviation standard.

Thus, higher doses of $\mathrm{GA}_{3}$ induced a smaller distribution of emergency over time.

\section{DISCUSSION}

A few studies in the literature on fruit/seed biometry of abarco found similar results in comparison to our study, despite being carried out in different biogeographical regions of Colombia. For the of the Middle Magdalena Valley region in the municipality of San Luis Antioquia (Antioquia), Diez and Moreno (1998) found that fruits $(6$ to $8 \mathrm{~cm}$ of length, $5.5 \mathrm{~cm}$ of width and 10 to 25 seeds per fruit) and seeds ( $4 \mathrm{~cm}$ of length, and $6.6 \mathrm{~cm}$ of width) had similar values to the ones found in the current study. The number of seeds per kilogram was 6237. For the Lower Chocoan Atrato-Urabá region in the municipality of Riosucio, Betancur and Raigosa (1973) found that the dimensions of fruits and seeds were almost identical.

As an exception, in the Sinu River Basin region in the municipality of Tierralta, Córdoba, Espitia et al. (2017) found that the number of seeds per kilogram varied abruptly, i.e. between 7082 up to 3/390 and with an average of 19498 seeds per kilogram. The dimension differences observed could indicate the interaction between environmental factors and genetic diversity, as well as the maturity state of fruits and their development process during harvest, since they can vary between and within trees, or between years for the same biogeographic zone (Silva et al., 2013; Bezerra et al., 2012; Cangussu et al., 20I8).
The Cariniana genus has evolved an anemochoric dispersion mechanism (Prance and Mori, 1978). According to the average dimensions observed in the current study (width of $49.6 \mathrm{~mm}$ and length of $76.1 \mathrm{~mm}$ ), the seeds of the individuals of $C$. pyriformis sampled could be classified as small, elongated and of low weight, factors that contribute to their dispersion. In fact, the characteristics of the diaspore (shape, mass and morphometry) can have a relative effect on its mobility, with wind speed and tree height being the most important factors determining the dispersion distance (Zhu et al., 20I6).

Initially, abarco seeds registered an average water content of $10.9 \%$ and a variation between 9.1 and $13.4 \%$ (Table 3), which could confirm its intermediate orthodox behavior as reported for this species by Betancur and Raigosa (1973). The authors confirmed that abarco seeds conserve much better their germinative potential when stored at $4{ }^{\circ} \mathrm{C}$ for 30 days (72\%) as opposed to $20^{\circ} \mathrm{C}$ for 90 days (35\%). Namely, from 60 days and under environmental temperature conditions, loss of seed viability begins. Seeds of $C$. legalis and $C$. estrellensis, other species of the Cariniana genus might also be classified as orthodox (Azevedo, 2009; Gómez, 2010; Kopper et al., 2010). However, it is necessary to deepen further the ideal conditions to store abarco seeds for longer periods in different environments and packaging.

Mosquera et al. (2012) and Espitia et al. (2016) found a germination percentage in abarco of 75 and $70 \%$, respectively, in seeds immersed for 24 hours in water and cultivated with sand substrate. The values 
were superior to the control treatment found in this study $(5 \mathrm{I} .1 \%)$, demonstrating the high variability of the results under similar germination conditions for this native species.

The use of $\mathrm{GA}_{3}$ allowed emergency percentage to increase from $5 \mathrm{I} .1$ to $73.5 \%$ and decrease the MET from 37.6 to 27.4 days with immersion using the highest dose (Figure 3), and revealing its usefulness. That is, although a value of $5 \mathrm{I} .1 \%$ without applying a phytoregulator could be considered acceptable, the results observed are important since seed supply may be compromised at certain times of the year as mentioned above. In addition, a long germination time makes forest seeds more susceptible to pathogen attack. According to Piveta et al. (2014), a shorter period decreases losses in the nursery, even once the plantation has been established. For $C$. pyriformis seeds harvested in forest areas of the department of Córdoba, the presence of seven genera of fungi was identified ranging between I and $77 \%$ of external incidence (Campo et al., 20I4). This leads to unviable commercialization.

C. pyriformis is a native species that demonstrates its ability to adapt to a changing environment showing a higher delay and heterogeneity in seedling emergency process, evidenced in the control treatment. This behavior increases the chances of finding more favorable conditions for seedling establishment. Furthermore, this type of relative dormancy, common in native species, ensures that at least part of the seeds germinate and develop (Berger et al., 2014). According to the classification described by Baskin and Baskin (2004) and based on the fact that there was permeability in the seed cover to the phytoregulator, it is suggested with the current study that a certain amount of abarco seeds might have seeds might have non-deep physiological dormancy: $\mathrm{GA}_{3}$ promotes germination. Further, other separate or combined pregerminative treatments, such as warm moist stratification or alternation of temperatures to break dormancy in abarco, should be evaluated because these treatments have proven to be effective with this type of dormancy in other forestry species (Pipinis et al., 20I4; Cabello et al., 2019).

From a nursery perspective, the main interest is to increase the emergency speed and synchrony processes, because it facilitates the tasks of selecting and transplanting uniform seedlings, increasing the efficiency of the production cycle. Clearly, the dose de $1000 \mathrm{mg} \cdot \mathrm{L}^{-1}$ generated a slightly higher emergency compared to the dose of $750 \mathrm{mg} \cdot \mathrm{L}^{-1}$ contributing to this goal, meanwhile the other treatments resembled more closely the control.

There was no detrimental effect with the doses evaluated for this study. Piveta et al. (2014) verified that increasing immersion time of Lithraea molleoides (Vell.) seeds in $\mathrm{GA}_{3}$ increased germination using a low concentration (48 hours and $250 \mathrm{mg} \cdot \mathrm{L}^{-1}$ ) than the opposite ( 24 hours and $500 \mathrm{mg} \cdot \mathrm{L}^{-1}$ ). In Vitex montevidensis Cham, another species of forest and ecological interest, Malavasi et al. (20I I) concluded that the application of $200 \mathrm{mg} \cdot \mathrm{L}^{-1}$ of $\mathrm{GA}_{3}$ for 47 hours allowed increasing the germination from 19 to $56 \%$.

In the future, it would be convenient to evaluate the combination of times and $\mathrm{GA}_{3}$ concentrations in abarco seeds, in addition to finding the optimum maturity state of fruits, storage conditions and times, pre-germination treatments, among other factors. No published information on the use of $\mathrm{GA}_{3}$ or other growth regulators in this species was found, so the knowledge continues to be scarce.

\section{CONCLUSIONS}

Major variability in the fruit fresh mass and number of seeds per fruit in abarco was verified in this study; furthermore, significant differences in all the biometric variables assessed among seeds and fruits of mother trees was evidenced. Mature abarco seeds seem to have nondeep physiological dormancy. Therefore, the application of gibberellins at a dose of $1000 \mathrm{mg} \cdot \mathrm{L}^{-1}$ for 24 hours is recommended because it increases, accelerates and synchronizes the seedlings emergency of reaching $71 \%$.

\section{ACKNOWLEDGEMENTS}

The Authors wish to thank AGROSAVIA ascribed to Ministerio de Agricultura y Desarrollo Rural de Colombia (MADR) for financing this study. This work was part of the Project "Strategies for forest plantation planning and management in Colombian agroecosystems" (January 2014 to December 20I7), belonging to Red de Innovación de Cultivos [Crop Innovation Network] of AGROSAVIA.

\section{REFERENCES}

AGUDELO - CASTAÑEDA, G.; CADENA - TORRES, J.; ALMANZA - MERCHÁN, P.; PINZÓN - SANDOVAL. Desempeño fisiológico de nueve genotipos de cacao (Theobroma cacao L.) bajo la sombra de tres especies forestales en Santander, Colombia. Revista Colombiana de Ciencias Horticolas, v. I2, n. I, p. 223-232, 2018.

AZEVEDO, D. Bases fisiológicas para a conservação a longo prazo de sementes de Cariniana legalis (Mart.) O. Kuntze. 2009. 80 p. PhD thesis. Universidade Estadual Paulista Julio de Mesquita Filho, São Paulo.

BASKIN, J.; BASKIN, C. A. classification system for seed dormancy. Seed Science Research, v. I4, p. I-I6, 2004.

BERGER, A. P; RANAL, M.; SANTANA, R. G. Variabilidade na dormência relativa dos diásporos de Lithraea molleoides (Vell.) Eng. Ciência Florestal, v.24, n.2, p. I-I3, 2014. 
BETANCUR, G.; RAIGOSA, J. Características y propiedades germinativas de las semillas de abarco (Cariniana pyriformis Miers). Revista Facultad Nacional de Agronomía, v. 28, n. 2, p. 36-56, 1973.

BEZERRA, F. T.; ANDRADE, L.; BEZERRA, M. A.; PEREIRA, W.; FABRICANTE, J. R.; OLIVEIRA, L.; FEITOS, R. Biometria de frutos e sementes e tratamentos pré-germinativos em Cassia grandis L. f. (Fabaceae). Semina: Ciências Agrárias, v. 33, supl. I, p.2863-2876, 2012.

BRASIL. Ministério da Agricultura e Reforma Agrária. Regras para análise de sementes. Brasília: SNDA/DNDV CLAV, 2009. 365 p.

CABELLO, A.; ESPINOZA, N.; ESPINOZA, S.; CABRERA, A.; SANTELICE, R. Effect of pre-germinative treatments on Nothofagus glauca seed germination and seedling growth. New Zealand Journal of Forestry Science, v.49, n.3, p. I-9, 2019.

CAMPO, R.; URANGO, N.; ESPITIA, M. Hongos asociados a la semilla de seis forestales nativos, cultivados en el departamento de Córdoba. Fitopatología Colombiana, v.38, n.2, p.27-3I, 2014.

CANGUSSU, A. C.; CAETANO, A. P.; SANTOS, J.; FILHO, M.; CARDOSO, A. Biometric analysisand breaking of dormancy of seeds of Piptadenia viridiflora (Kunth) Benth. Floresta, v.48, n.3, p.355-362, 2018.

CÁRDENAS, D.; CASTAÑO, N.; SUA, S.; QUINTERO, L.; BERNAL, M.; GUERRERO, S. et al. Planes de manejo para la conservación de abarco, caoba, cedro, palorosa y canelo de los andaquíes. SINCHI - Ministerio de Ambiente. Vivienda y Desarrollo Territorial, 20 I5, p. I I-74.

DIEZ, M. C.; MORENO, F. Morfología de semillas y plántulas de árboles de los bosques húmedos tropicales del suroriente de Antioquia, Colombia (I parte). Revista Facultad Nacional de Agronomía, v.5I, n.2, p.9-50, 1998.

ESPITIA, M.; CARDONA, C.; ARAMÉNDIZ, H. Pruebas de germinación de semillas de forestales nativos de Córdoba, Colombia, en laboratorio y casa-malla. Revista U.D.C.A Actualidad \& Divulgación Científica, v.9, n.2, p.307$315,2016$.

ESPITIA, M.; ARAMÉNDIZ, H.; CARDONA, C. Características morfométricas, anatómicas y viabilidad de semillas de Cedrela odorata L. y Cariniana pyriformis Miers. Agronomía Mesoamericana, v.28, n.3, p.605-617, 2017.

GOMEZ, M. L. Fenología reproductiva de especies forestales nativas presentes en la jurisdicción de CORANTIOAQUIA, un paso hacia su conservación. Volumen II. CORANTIOQUIA, 2010, p.63-662.

HUANG, Y. Y.; MORI, S. A.; KELLY, L. M. Toward a phylogeneticbased generic classification of neotropical Lecythidaceae - I. Status of Bertholletia. Corythophora. Eschweilera and Lecythis. Phytotaxa, v.203, n.2, p.85-I2I, 2015.

KARSTEN, R. J.; MEILBY, H.; LARSEN, J. B. Regeneration and management of lesser known timber species in the Peruvian Amazon following disturbance by logging. Forest Ecology Management, v.327, p.76-85, 2014.
KÖPPEN, W. Klassifikation der Klimate nach Temperatur, Niederschlag und Jahresablauf (Classification of climates according to temperature, precipitation and seasonal cycle). Petermanns Geogr. Mitt., I9I8, p.243-248.

KOPPER, A. C.; MALAVASI, M. M.; MALAVASI, U. C. Influência da temperatura e do substrato na germinação de sementes de Cariniana estrellensis (Raddi) Kuntze. Revista Brasileira de Sementes, v.32, n.2, p.I60-165, 2010.

MALAVASI, M.; DIAS, G.; MALAVASI, U. Effect of gibberellic acid and temperature on germination of Vitex montevidensis Cham. Cerne, v. I7, n.2, p.203-207, 201 I.

MORI, S. A.; KIERNAN, E. A.; SMITH, N. P.; KELLEY, L. M.; HUANG, Y. Y.; PRANCE, G. T.; THIERS, B. Observations on the phytogeography of the Lecythidaceae clade (Brazil nut family), Phytoneuron, v.30, p. I-85, 2017.

MOSQUERA, D.; MEDINA, H.; MARTÍNEZ, M. Germinación y crecimiento inicial en abarco Cariniana pyriformis: una alternativa para su conservación. Biodiversidad Neotropical, v.2, n.I, p.53-59, 2012.

NICODEMO, M. L.; MULLER, M. D.; PORFÍRIO-DA-SILVA, V.; CARPANEZZI. A. A.; PEZZOPANE, J. R.; BARIONI, W. Growth of native trees in two agroforestry systems. Arvore, v.40, n.4, p.639-648, 2016.

PIPINIS, E.; MILIOS, E.; MAVROKORDOPOULOU, O.; LOZOS, P.; SMIRIS, P. Dormancy-breaking requirements and germination for seeds of Ostrya carpinifolia Scop. Notulae Botanicae Horti Agrobotanici Cluj-Napoca, v.42, n.l, p.209-2I3, 2014.

PIVETA, G.; BRIÃO, M.; SILVEIRA, M.; BRAGA, C.; Pacheco, C. Qualidade sanitária e fisiológica de sementes de aroeira-preta (Lithraea molleoides) submetidas a métodos de superação de dormência. Ciência Florestal, v.24, n.2, 2014.

PRANCE, G. T.; MORI, S. Observations on the fruits and seeds of neotropical Lecythidaceae. Brittonia. v.30, n. I, p.21-33, 1978.

RANAL, M. A.; SANTANA, D. G. How and why to measure the germination process?. Revista Brasileira de Botânica, v.29, n. I, p.I-I I, 2006.

R CORE TEAM. R: A language and environment for statistical computing. R Foundation for Statistical. 2017.

SILVA, M.; BORGES, E.E.; LEITE, H.G.; CORTES, V. Biometria de frutos e sementes de Melanoxylon brauna Schott. (FabaceaeCaesalpinioideae). Cerne, v.19, n.3, p.517-524, 2013.

SMITH, N. P.; MORI, S. A.; PRANCE, G. T. Jardim Botânico do Rio de Janeiro. Lista de Espécies da Flora do Brasil. 20I5. Available at: http://floradobrasil.jbrj.gov.br/jabot/ floradobrasil/FB I45. Accessed in: 21 june 2018.

SUAREZ, J. C.; MELGAREJO, S.; CASANOVES, F; DI RIENZO, J.A, DAMATTA, F. M; ARMAS, C. Photosynthesis limitations in cacao leaves under different agroforestry systems in the Colombian Amazon. Plos One, v. I3, n. II, e0206 I49, p. I-13, 2018. 
ZHU J.; LIU, M.; XIN, Z.; ZHAO, Y.; LIU, Z. Which factors have stronger explanatory power for primary wind dispersal distance of winged diaspores: the case of Zygophyllum xanthoxylon (Zygophyllaceae)?. Journal of Plant Ecology, v.9, n.3, p. 346-356, 2016.
PELAEZ, J. J.; PRATO, A. I.; ZAPATA, L. P.; ZARATE, D. A. Phenology of Cariniana pyriformis in the Magdalena Medio region of Santander, northeastern Colombia. Pesquisa Florestal Brasileira. v.38, e20I70I4I4, p. I-6, 20 I8. 